\title{
Innovations
}

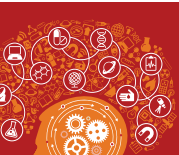

\section{The Zar (Bori) Cult: A proposed integrated psychotherapy module}

\author{
Medical Humanities in the Middle East Conference
}

November 17-18, 2018

Doha, Qatar

\section{Authors}

Nahid M. Elhassan', Ahmed Al Safi ${ }^{2}$, Abdalla A. B. Khairil+ $^{\text {+ }}$

\section{Abstract}

The zar cult has been described as a dramatic performance, a folk drama, a psychodrama, or a ritual psychodrama." "Like festivals and other forms of folk drama, zar combines different genres such as singing, drumming and dancing. It also involves and utilizes artistic expressions and methods such as folk costumes, conventional theatrical devices, make-up, incense, etc. Moreover, the zar rituals take place in a festive mood of feasting and offerings of sacrifices. ${ }^{1}$

As folk dramatic performance, zar rituals are psychotherapeutic interventions involving a fullfledged, well-prepared folk theatre. The rituals are woven around the needs of the "zar bride," which were carried out to fulfill her wishes. She chooses the time, place and duration of the ceremony. During performance, she is seated in the centre stage, and given priority in dancing whenever she feels like doing so.

The shaikha (female zar officer), the charismatic stage director and master of ceremonies, is in full command of the stage. She generates an orchestrated, animated, continuous interaction between drummers, singers and dancers and leads it skillfully to a climax. To achieve this end, a prompter who is also present, keeps spirits up, sustains the required tempo and vitality of the performance, and ensures total involvement.'

The musical ensemble is composed of experienced drummers and singers. The actors (zar bride, zar patients or victims) and audience (zar fraternity members or curious neighbours) join together in
'Hamad Medical Corporation, Doha, Qatar

2 Ibn Sina University, Khartoum, Sudan

*Email: ahmadalsafi@gmail.com

+Email: AKhairi1@hamad.qa

\section{Cite this article as:}

Elhassan NM, AI Safi A, Khairi AAB. The Zar (Bori) Cult: A proposed integrated psychotherapy module. In: Weber AS, Verjee MA, editors. Proceedings of the 1st International Conference on Medical Humanities in the Middle East [Internet]; 2018 Nov 17-18: Doha, Qatar: Innovations in Global Health Professions Education; 2019 March. p. 33-35. (Innovations in Global Health Professions Education; vol. 2019, spec. no.: 1). https://dx.doi.org/10.20421/ighpe2019.01.11

This is an open access article distributed under the terms of the Creative Commons Attribution license CC BY 4.0, which permits unrestricted use, distribution and reproduction in any medium, provided the original work is properly cited. 
one celebratory group; all dressed in their best. They dance (perform) to zar rhythmic music in a joyous atmosphere. The distinctive zar incense ${ }^{2}$ and the various perfumes carried by the participants, saturate the air. Drummers, actors and audience enjoy the lavish feast that they eat together, and in the old days, took the liberty of drinking refined alcoholic beverages, smoked cigarettes, and ate exotic Western food.

Zar is practiced in several West, East and North African and Middle Eastern countries. It has been likened to Haitian Voodoo. ${ }^{3}$ The zar clientele is formed mainly of female patients who were labeled as suffering from psychoneurotic conditions, attributed to sexual frustration and inferior socio-cultural status, ${ }^{6}$ or women of histrionic personalities.

Zar is a predominantly women's healing cult believed to cure illness, alleviate the manifestations of misfortune, or resolve conflict alleged to be due to the invasion or possession by 'zar spirits' that influence health and disease. The renowned Tigani El Mahi contends that in psychiatric management of some cases, zar proved to be a more reliable alternative than dream interpretation. He concluded that the zar archetypes stand for specific types of personality traits whose moods, temperaments and predispositions are manifest. ${ }^{2}$

Zar is alleged to be therapeutically beneficial as a form of group therapy and psychodrama. ${ }^{5}$ The various modalities mobilized in the group setting of zar allow for special support, identification, projection, abreaction and socially accepted ventilation of in-bent emotions. ${ }^{6}$ It is also thought that the therapeutic effect of zar could be due to possible hypnosis, psychoanalysis and catharsis.

This project hypothesizes that effective crosscultural diagnostic, psychoanalytic and therapeutic tools in zar and similar cults could be established. To verify this claim, the project also verifies whether zar achieves total cure, partial treatment, alleviates symptoms or only relieves tension. The contribution of each element of the zar cult will be tested using the most rigorous methods of assessment and measurement science has provided.
Conflicts of interest: None.

Funding sources: None.

\section{References}

1. Hurreiz S. Zar as ritual psychodrama: from cult to club. In: Lewis IM, El Safi A, Hurreiz SHA, editors. Women's medicine: the Zar-Bori cult in Africa and beyond. Edinburgh, Scotland: Edinburgh University Press; 2011. p. 147-155.

2. El Safi A. Traditional Sudanese medicine: a primer for health care providers, researchers, and students. Khartoum, Sudan: Azza House; 2007. p. 140.

3. Sargant W. Battle for the mind: a physiology of conversion and brain-washing. London, England: Heinemann; 1957. 248 p.

4. Lewin B. Der Zar, ein agyptischer Tanz zur Austreibung boser Geister bei Geisteskrankheiten, und seine Beziehungen zu Heiltanzzeremonien anderer Volker und Tanzwut des Mittelalters. Confin Psychiatr. 1958;1:177-200.

5. Baasher TA. Some aspects of the history of the treatment of mental disorders in Sudan. In: López Ibor JJ, editor. The important factors influencing mental health in some African and Near Eastern countries. Proceedings of the 4th World Congress of Psychiatry: 1966 Sep 5-11; Madrid, Spain. New York, NY: Exerpta Medica; 1968.

6. Baasher TA. The Arab countries. In: Howells JG, editor. World history of psychiatry. New York: Brunner; 1975. p. 547-578. 


\section{About the authors}

Dr. Nahid Mohammed Alhassan Ali, MBBS, MD, is a Clinical Fellow and Consultation Liaison in the Psychiatry Department at Hamad Medical Corporation in Doha, Qatar since 2015. She received the William Friedrich Memorial Child Sexual Abuse Research, Assessment \&/or Treatment Award from the Family Violence \& Sexual Assault Institute and Institute on Violence, Abuse \& Trauma in 2016. In 2014, she was the President of the Psychiatric Department at the University of Medical Science and Technology and an award winner from the Arab Psychiatrist Federation for best research. She was Director of the Positive Discipline Program at the Child Rights Institute from 2007-2014 and Vice President of the Sudanese Writers Union from 2008-2009. She is an Activist in the field of women and child protection and has published several papers and books, as well as columns for major Sudanese newspapers.

Prof. Ahmed El Safi, MBBS, DA, FFARCS, FRCA, is an Anaesthesiologist at Ibn Sina University, Khartoum, Sudan as well as Director of the Sudan Medical Heritage Foundation. He has been a top administrator at several institutions, including: Director, Maharat Medical Training Centre; Director, Al Jawda Hospital; and Director, Ibrahim El Zain Training Centre. He also serves in important leadership roles such as President, Sudanese Writers Union and President, Sudanese Society of Anaesthesiologists.

Dr. Abdalla A. B. Khairi, MBBS, MDeligPsych, MCspsych, ABMSpsych, is a consultant psychiatrist in the Mental Health Hospital, Hamad Medical Corporation. He graduated from Juba University (Southern Sudan) in 1988. He served as a psychiatrist in Sudan, Qatar and the UK. He initially trained in Sudan towards the MD. Psych. Degree, then joined HMC to continue his training via the Arab Board of Medical Specialization Psych. Program. He joined the Wales University (UK), School of Medicine post-graduate program to attain an MSc degree in psychiatry. This was an opportunity to express his keen interest in cultural psychiatry, a career path he followed towards becoming a community activist and literary writer; publishing books and delivering public awareness talks in the field of mental health and other related fields. Related to this is his contribution to establishing and developing the older Adult Community Psych. Services in Qatar. Of note is to mention that Dr Khairi has been awarded the certificate of clinical academic excellence from Weill Cornell Medicine - Qatar in 2005 as recognition for his contribution to teaching and training students. 